"The impact of fiscal councils on the budgetary consolidation"

\begin{tabular}{|c|c|c|}
\hline AUTHORS & \multicolumn{2}{|l|}{$\begin{array}{l}\text { Ante Žigman } \\
\text { Martina Jergović }\end{array}$} \\
\hline ARTICLE INFO & \multicolumn{2}{|c|}{$\begin{array}{l}\text { Ante Žigman and Martina Jergović (2017). The impact of fiscal councils on the } \\
\text { budgetary consolidation. Public and Municipal Finance, } 6(1), 15-23 \text {. } \\
\text { doi:10.21511/pmf.06(1).2017.02 }\end{array}$} \\
\hline DOI & \multicolumn{2}{|c|}{ http://dx.doi.org/10.21511/pmf.06(1).2017.02 } \\
\hline RELEASED ON & \multicolumn{2}{|l|}{ Wednesday, 05 April 2017} \\
\hline & \multicolumn{2}{|l|}{$(\boldsymbol{c c}) \mathbf{E Y}$} \\
\hline LICENSE & \multicolumn{2}{|c|}{$\begin{array}{l}\text { This work is licensed under a Creative Commons Attribution } 4.0 \text { International } \\
\text { License }\end{array}$} \\
\hline JOURNAL & \multicolumn{2}{|l|}{ "Public and Municipal Finance" } \\
\hline ISSN PRINT & \multicolumn{2}{|l|}{$2222-1867$} \\
\hline ISSN ONLINE & \multicolumn{2}{|l|}{$2222-1875$} \\
\hline PUBLISHER & \multicolumn{2}{|c|}{ LLC "Consulting Publishing Company "Business Perspectives" } \\
\hline FOUNDER & \multicolumn{2}{|c|}{ LLC "Consulting Publishing Company "Business Perspectives" } \\
\hline \multirow{2}{*}{ NUMBER OF REFERENCES } & & 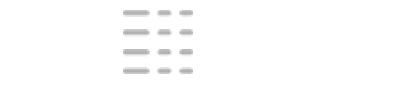 \\
\hline & NUMBER OF FIGURES & NUMBER OF TABLES \\
\hline 15 & 2 & 9 \\
\hline
\end{tabular}

(C) The author(s) 2022. This publication is an open access article. 
Ante Žigman (Croatia), Martina Jergović (Croatia)

\title{
The impact of fiscal councils on the budgetary consolidation
}

\begin{abstract}
Fiscal councils are independent institutions that play an important role in execution of fiscal rules and budgetary discipline through their realistic and unbiased macroeconomic and budgetary analysis and projections. It is important that the fiscal councils have easy access to the media to ensure that their analyses reach the wider public, and influence creators of fiscal policy. This paper analyzes the influence of fiscal councils on budget balance and public debt in period before and after financial crisis. The member states that had functioning fiscal councils before the financial crisis, on average, manage their public finances better than those who founded them after the beginning of crisis. Additionally, supervision of the enforcements of fiscal rules from fiscal boards is already showing positive results in this short time period. Fiscal councils are extremely important to ensure a healthy basis for conducting fiscal policy and to decrease the influence of politics on public finance management.
\end{abstract}

Keywords: budget balance, fiscal councils, fiscal rules, public debt.

JEL Classification: H1, H62, H63.

\section{Introduction}

The sovereign debt crisis raised the issue of the weaknesses of the economic framework for the management of public finance in the world, and the EU has given special attention to it, especially within the European Monetary Union, wherever complex and demanding rules of public finance management are introduced. Independent fiscal councils and fiscal rules have become the backbone of public financial management in the European Union. In recent years, there is a demand for stricter enforcement of fiscal rules and, as a consequence, packages "six-pack" and "two-pack" have been adopted, and the majority of EU member states signed the "Fiscal Compact". Member states are expected to strengthen national institutions for the implementation of fiscal policy in order to ensure long-term sustainability of public finances. Authors tried to assess the impact of fiscal councils on the budgetary consolidation before financial crisis of 2008 and after financial crisis with special accent on countries, which established independent fiscal institutions well before financial crisis. This paper starts with literature overview that explains theoretical framework of the fiscal councils with special case of Croatia, after which analyzes the impact of the fiscal councils on the consolidation of public finance, and, at the end, there is a conclusion.

\section{Literature overview}

There are number of papers on fiscal councils and some of them are dealing with effectiveness of independent fiscal institutions. There is a paper from authors Beetsma and Debrun, which is dealing with effectiveness of fiscal councils. Their paper

(C) Limited Liability Company "Consulting Publishing Company "Business Perspectives", 2017.

Ante Žigman, Ph.D., Zagreb School of Economics and Management, Croatia.

Martina Jergović, bacc. oec., Zagreb School of Economics and Management, Croatia. discusses effectiveness and rationale of independent fiscal institutions, which is another name of fiscal councils. In general, they defined fiscal councils as independent institutions from creators of fiscal policy. They present that independent fiscal institutions are contributing to better public understanding of quality of fiscal policies. There is also important improvement in voter decision and policymaker's incentives (Beetsma and Debrun, 2016a). Another paper by Debrun, Kinda, Curristine, Eyraud, Harris and Seiwald extensively explain the functions and impact of fiscal councils. They also define fiscal councils as independent public institutions with various functions. There are following functions they single out: assessments of fiscal plans, evaluation of macroeconomic and budgetary forecasts. They conclude that fiscal councils are promoting fiscal discipline if fiscal councils are well designed (Debrun et al., 2013). Another book explains that important task of fiscal councils is to find where is the source of deficit bias (von Hagen, 2013). Recently there are comparisons between fiscal councils and central banks, but fiscal councils don't have policy tools to force creators of fiscal policy to carry out changes that will contribute to long-term fiscal sustainability. Fiscal councils can only use public space and convincing to steer in the right direction (Beetsma and Debrun, 2016b).

\section{The theoretical framework of the fiscal council}

Fiscal councils can play an important role in the implementation of fiscal policies and the implementation of budgetary discipline in order to provide a realistic and impartial macroeconomic and budgetary projections. The real and unbiased projections provide a sound basis for the preparation of the government budget. Overly optimistic projections that are often made in government institutions create unrealistic expectations that show overly optimistic revenue and, thus, lead to unrealistically high expenses that cause huge deficits and damaging the stability of public finances (ECB, 
2013). Therefore, there are defined conditions that fiscal councils should meet in order to be effective. The literature commonly referred to three conditions: the first relates to the independence of the fiscal council and their complete separation from the government, the second condition is that the fiscal councils should have a clearly defined mandate and the third condition relating to the instruments and measures in order to have influence on government (Wyplosz, 2012).

In general, the independent fiscal institutions are defined as an impartial public bodies, which are not part of the government or the Parliament. These institutions are primarily financed by public funds and functionally independent of the fiscal authorities (European Commission, 2016). The independent fiscal institutions, which can be also called fiscal councils, exist to impartially impact fiscal policy. Fiscal councils should influence the improvement of the decision making process by providing different types of analysis with which they can make recommendations and guidelines for fiscal policy. Also, fiscal councils should assist in the development of independent, realistic macroeconomic forecast. By providing the recommendations and guidelines to assist policy makers in the development and adoption of the budget, they are raising awareness on the shortand long-term costs and budgetary measures not only to the policy makers, but also to the public in order to ultimately be able to determine whether the measures of fiscal makers are appropriate in terms of compliance with the fiscal rules, the sustainability of public finance and the orientation of fiscal policy on sustainability. Through a comprehensive study in 2006, the European Commission services have been collected and published extensive information about national independent fiscal institutions in the European Union (European Commission, 2016). This study defines the major characteristics of fiscal institutions, their bodies, mandate duration and formal status. Through the years, data have changed on the number of fiscal councils and their functions. It is hard to determine the exact numbers of fiscal councils in the world, because the number varies in different sources. Considering the fact that this paper is based on independent fiscal institutions within the European Union, current number of fiscal councils is 26 (Table 1).

Table 1. List of independent fiscal councils in EU

\begin{tabular}{|l|l|c|}
\hline \multicolumn{1}{|c|}{ Country } & \multicolumn{1}{c|}{ Name of institution } & $\begin{array}{c}\text { Start of } \\
\text { activity }\end{array}$ \\
\hline Austria & Austrian Fiscal Advisory Council & 2002 \\
\hline Belgium & $\begin{array}{l}\text { High Council of Finance - section } \\
\text { "Public sector borrowing requirement" }\end{array}$ & 1989 \\
\hline Bulgaria & Fiscal council & 2015 \\
\hline
\end{tabular}

\begin{tabular}{|l|l|c|}
\hline Czech Republic & No information available & $/$ \\
\hline Cyprus & Fiscal Council & 2014 \\
\hline Croatia & Commission on Fiscal Policy & 2011 \\
\hline Denmark & Danish Economic Council & 1962 \\
\hline Estonia & Fiscal Council & 2014 \\
\hline Finland & National Audit Office & 2013 \\
\hline France & High Council on Public Finances & 2013 \\
\hline Greece & The Parliament's State Budget Office & 2010 \\
\hline Ireland & Irish Fiscal Advisory Council & 2011 \\
\hline Italy & Parliamentary Budget Office & 2014 \\
\hline Latvia & Fiscal Council & 2014 \\
\hline Lithuania & National Audit Office of Lithuania & 2015 \\
\hline Luxemburg & $\begin{array}{l}\text { The National Council of Public } \\
\text { Finance }\end{array}$ & 2014 \\
\hline Malta & The Malta Fiscal Advisory Council & 2015 \\
\hline Hungary & Fiscal Council & 2009 \\
\hline The Netherlands & Independent Budgetary Authority & 1945 \\
\hline Germany & $\begin{array}{l}\text { Stability Council/ Council of } \\
\text { independent experts }\end{array}$ & 1963 \\
\hline Poland & No information available & $/$ \\
\hline Portugal & Public Finance Council & 2011 \\
\hline Romania & Fiscal Council & 2010 \\
\hline Slovakia & Council for Budget Responsibility & 2011 \\
\hline Slovenia & $\begin{array}{l}\text { Institute of Macroeconomic Analysis } \\
\text { and Development }\end{array}$ & 1991 \\
\hline Spain & $\begin{array}{l}\text { Independent Authority of Fiscal } \\
\text { Responsibility }\end{array}$ & 2014 \\
\hline Sweden & Fiscal Policy Council & 2007 \\
\hline UK & Office of Budget Responsibility & 2010 \\
\hline
\end{tabular}

Source: national webpages of fiscal councils, the functions and impact of fiscal councils (MMF, 2013).

2.1. Contemporary fiscal councils. We have defined contemporary fiscal councils as those incurred after 2011. The work of national fiscal councils was established on the basis of the EU Directive on budgetary frameworks (2011/85/EU), which is part of the so-called "six-pack" (Juncker, 2015). The purpose and aim of this Directive is to provide a framework for the establishment of a unified fiscal council within the European Union. Most countries are in line with the Directive, but often the term "independence from politics" is understood in different ways. In some cases, fiscal councils stay close to the Ministry of Finance or the Parliament. The European Commission is trying through a series of recommendations to Member States to make clear that the fiscal councils should be independent and separate from the executive power or politics. It is unclear why it is not explicitly written in the Directive, but the European Commission through specific recommendations for member states (Eng. Country Specific Recommendation) tries to give clear guidelines on how to organize and accommodate fiscal council. One of the characteristics of modern fiscal council is to provide institutional credibility, which is the basis for effectively increasing the impact on the government to drop its unrealistic promises. Credibility is achieved through a high level of professionalism of 
the members of the fiscal council and by ensuring the independence of the influence of the executive authorities on the analysis and conclusions of the fiscal council (Calmfors \& Wren-Lewis, 2011).

An important task for contemporary fiscal council is to monitor the long-term fiscal sustainability rather than focus on one-year achievement of fiscal policy. In fact, with the assessment of current fiscal policies implementation, it is necessary to make analysis of the direction of fiscal policy to see how is viable the implementation of fiscal policy. In this context, fiscal councils must have access to information and staff who are trained and to processed data. It is of utmost importance that contemporary fiscal councils are influential in media so that their work can reach broader public opinion.

This instrument allows the fiscal councils to publicly ask government questions that must be responded publicly. It also allows the revision of government projections if they made them unrealistic and ask government to create more realistic projections (ECB, 2013).

2.2. Types of fiscal council. When we talk about the types of organization of the fiscal council, they can be divided into three groups. Fiscal councils can act as an independent institution, as an institution under the executive or legislative authorities and as an institution associated with another government institution.

2.2.1. Independent institution. Fiscal councils as independent institutions are the best example of an independent fiscal authorities, as proposed in the scientific literature. Independent institutions are completely separate from the government and their functional and political independence is beyond doubt. Such independent institutions have their own organization (IMF, 2013). Examples of the fiscal council, acting as an independent institution within the European Union are:

Table 2. Independent fiscal councils

\begin{tabular}{|l|l|}
\hline \multicolumn{1}{|c|}{ Country } & \multicolumn{1}{c|}{ Name of institution } \\
\hline Ireland & Irish Fiscal Advisory Council \\
\hline Luxemburg & The National Council of Public Finance \\
\hline Hungary & Fiscal Council \\
\hline Germany & Stability Council/ Council of independent experts \\
\hline Portugal & Public Finance Council \\
\hline Romania & Fiscal Council \\
\hline Slovakia & Council for Budget Responsibility \\
\hline Spain & Independent Authority of Fiscal Responsibility \\
\hline Sweden & Fiscal Policy Council \\
\hline
\end{tabular}

Source: national webpages of fiscal councils, the functions and impact of fiscal councils (MMF, 2013).

2.2.2. Fiscal councils under the government or state institutions. Fiscal councils under the government or state institutions can be fully legally separated or integrated in the executive or legislative authorities. It is essential that there is a certain level of independence and that the members of the board are non-partisan persons (IMF, 2013). Mandate duration and the manner of selecting board members should be clearly defined.

Table 3. Fiscal councils under the state institutions

\begin{tabular}{|l|l|}
\hline \multicolumn{1}{|c|}{ Country } & \multicolumn{1}{c|}{ Name of institution } \\
\hline Belgium & $\begin{array}{l}\text { High Council of Finance - section "Public sector } \\
\text { borrowing requirement" }\end{array}$ \\
\hline Bulgaria & Fiscal Council \\
\hline Cyprus & Fiscal Council \\
\hline Croatia & Commission on Fiscal Policy \\
\hline Denmark & Danish Economic Council \\
\hline Greece & The Parliament's State Budget Office \\
\hline Latvia & Fiscal Council \\
\hline Malta & The Malta Fiscal Advisory Council \\
\hline The Netherlands & Independent Budgetary Authority \\
\hline UK & Office of Budget Responsibility \\
\hline
\end{tabular}

Source: national webpages of fiscal councils, the functions and impact of fiscal councils (MMF, 2013).

2.2.3. Fiscal council associated with another independent institution. Fiscal councils associated with another independent institution are usually within the central bank, the State Audit Office or the independent statistical agency. This approach allows from the start a political and functional independence. Also one of the positive things of this kind of fiscal councils is economies of scale. What is important is a clear separation of functions and mandate of other independent institutions and fiscal council (IMF, 2013). Examples of such fiscal council are found in Table 4.

Table 4. Fiscal councils associated with another independent state institution

\begin{tabular}{|l|l|}
\hline \multicolumn{1}{|c|}{ Country } & \multicolumn{1}{c|}{ Name of institution } \\
\hline Austria & Austrian Fiscal Advisory Council \\
\hline Estonia & Fiscal Council \\
\hline Finland & National Audit Office \\
\hline France & High Council on Public Finances \\
\hline Italy & Parliamentary Budget Office \\
\hline Lithuania & Fiscal Council \\
\hline Slovenia & Institute of Macroeconomic Analysis and Development \\
\hline
\end{tabular}

Source: national webpages of fiscal councils, the functions and impact of fiscal councils (MMF, 2013).

Although currently there are three types of organization of independent fiscal institutions, according to the Directive (85/2011/EU), the tendency is that the structure of each is in the form of an independent institution. Therefore, it is expected that, over a longer period of time, every country in the European Union has its own independent fiscal institution to be in order to maintain the most important principle of functional and political independence.

2.3. Functions of the fiscal council. The main functions of the fiscal council are arising from their definition. Almost all of the functions of the fiscal council overlap with activities of the Ministry of Finance and other bodies concerned with economic 
analysis. Therefore, it is not necessary that the fiscal council performs each of the functions, but functions of the fiscal council must provide unbiased and realistic overview of the economic and fiscal situation in country. Past practice has shown that the institutions dealing with economic analysis and which are managed by Government typically created biased and unrealistic economic projections that led to pro-cyclical fiscal policy. Functions vary from country to country and are listed and explained below.

2.3.1. An independent analysis, review and monitoring of the government's fiscal policy, plans and performance. The fiscal council may conduct analyses and ex-ante and ex-post evaluation of fiscal policy. Ex-ante implies that they give guidance, analysis and proposals, while ex-post implies on the assessment of the effectiveness of the implementation of fiscal policy. It is important that, for example, annual or semi-annual government budget proposals are in accordance with the fiscal rules, the long-term sustainability of public finance and the associated risks. It is also important that the fiscal councils do not provide analysis related only to the budget, but about everything that has an impact on the adequacy of public finances and the implementation of fiscal policy, which includes the effect of the labor market, the impact of an aging population and the scope of the tax burden (IMF, 2013).

2.3.2. Development of macroeconomic and/or budgetary projections. In addition, the analysis provided by the ratings given by the Government in terms of fiscal policy and fiscal councils can also help in the development of macroeconomic and/or budgetary projections. This means that their impartial research can take part in the creation of projections or they can determine the key assumptions and parameters in the creation of macroeconomic and fiscal projections.

Also, in the event of a significant difference between the projections and the actual budget, the fiscal council is entitled to request an explanation from the government why these significant differences occurred, and the Government generally required to respond to the fiscal council and the public display this communication (IMF, 2013).

\subsubsection{Analysis of the costs of budget and policy} proposals, including possibly the election programs. The fiscal council may be responsible for making realistic evaluation of policy measures, as it is considered that due to their functional independence may give a more accurate estimate than political parties (IMF, 2013). The best indicator are parliamentary elections in Croatia where political programs are full of unrealistic and financially unsustainable promises.

An independent and credible analysis of professional bodies such as the fiscal council can contribute to the fact that political parties refrain from such unrealistic promises, because they know that they will be publicly rated.

\subsubsection{Advising policymakers on policy options.}

Function of consulting creators of fiscal policy means the right to comment and provide recommendations on any political or specific issue that must be resolved by consensus. Specific questions are related to the situation where a consensus should be adopted, but political parties are strongly opposed so there is the possibility of making the wrong decisions. Function of fiscal council in this situation is to make an impartial recommendation or comment, which affects the decision of policy makers which is, then, not politically formed decision (IMF, 2013).

2.4. Fiscal council in Croatia. After the financial crisis recommendation of the international financial institutions (International Monetary Fund and World Bank) to Croatia was to produce a basis for the establishment of an independent fiscal authority to control fiscal policy. In Croatia, the effect of the fiscal council may be divided into two periods: from 2011 to 2013 and from 2013 to 2016. From 2011 to 2013, it existed as a Fiscal Policy Committee.

\subsubsection{Fiscal Policy Committee. Fiscal Policy} Committee was founded on 25 March 2011 by the Government. The Committee was established as a professional and independent body in order to improve the public finance system and monitoring the implementation of fiscal rules established by the Fiscal Responsibility Act (Government, 2011). The objective of the establishment of the Fiscal Committee was to increase transparency, fiscal discipline and the sustainability of public finances. The council had seven members and the President which was Minister of Finance.

The mandate of the Committee was planned to be five years, and the members were appointed by the Government. Its Chairman was Minister of Finance, but without the right to vote and all decisions are brought members of the Committee. The idea was that the two members of the Committee (the representatives of the Faculty of Economics), exchange the mandates, particularly in the first half of mandate, the representatives would be from the Faculty of Economics in Zagreb and Split, and in other half, the representatives of the Faculty would be from the Faculty of Economics in Osijek and Rijeka. 
Fiscal Committee was under executive authority of the political system and its administrative tasks were performed by the Ministry of Finance. That makes Fiscal Committee dependent on Government which is not in line with spirit of independence.

The tasks of the Fiscal Committee were established by the Decision on the establishment of the Committee on fiscal policy:

- review and assessment of the implementation of fiscal rules established by the Law on fiscal responsibility in the proposal of the Croatian budget for the fiscal year and projections for the next two years and proposals of financial plans of supplementary state budget;

- review and assessment of the implementation of fiscal rules established by the Law on fiscal responsibility in the draft amendments to the Croatian budget and proposed amendments to the financial plans of supplementary state budget;

- review and assessment of the implementation of fiscal rules established by the Law on fiscal responsibility in the draft semi-annual and annual reports on the execution of the Croatian budget and report on the implementation of fiscal rules;

- review and assessment documents issued by the Croatian Government, and are related to the process of development of the Croatian budget and projections;

- review and assessment of measures to improve the efficiency and sustainability of public finances (Government, 2011).

The problem with this structure of Fiscal Committee was questionable independence from the executive authority with respect to the fact that the President was Minister of Finance, and that all administrative tasks were performed by the Ministry of Finance. Consequently, 2013 Fiscal Committee becomes Commission on fiscal policy in Parliament and partially changes organizational structure.

2.4.2. Commission on fiscal policy. Croatian Parliament on 28 December 2013 made a decision on the establishment of the Commission on fiscal policy. Commission was defined in the same way as the Fiscal Committee. The most important change is that the Commission Chairman is no longer a Finance Minister, but the President of the Committee for Finance and Budget of the Croatian Parliament who is also a member of the Committee. There are issues concerning that President of Commission is a political person.

Appointment of Members of the Commission is carried out by the Croatian Parliament. Members are elected for a period of five years and may be reelected. Representatives of Economic and Legal Faculties are exchanged. Other members of the
Commission are proposed to Finance and Central Budget Committee by the institutions they are working at (the State Audit Office, the Institute of Economics, Institute of Public Finance, the Croatian National Bank). The main task of the Commission is to monitor the implementation of the fiscal rules established by the Fiscal Responsibility Act. Other tasks of the Commission are:

- review and assessment of the implementation of fiscal rules established by the Fiscal Responsibility Act in the draft state budget and financial plans of extra-budgetary users of the state budget for the fiscal year and projections for the next two years;

- review and assessment of the implementation of fiscal rules established by the Fiscal Responsibility Act in the draft amendments to the state budget and financial plans of extrabudgetary users of the state budget;

- review and assessment of the implementation of fiscal rules established by the Fiscal Responsibility Act in the draft semi-annual and annual report on execution of the state budget and financial plans of extra-budgetary users of the state budget;

- review and assessment of the implementation of fiscal rules established by the Fiscal Responsibility Act in the documents issued by the Croatian Government, and are related to the process of drafting the state budget and the budgets of local and regional governments and financial plans of extra and projections for the medium-term budget period;

- consideration and comparison of macroeconomic and budgetary projections to the latest available projections of the European Commission in the documents issued by the Croatian government or the Croatian Government proposed to the Parliament, and that are related to the process of drafting the state budget and the budgets of local and regional government and financial plans of extra and projections for the mediumterm budget period;

- identification of the disaster, and the existence of major economic disturbances that have a significant impact on the financial position of the general budget, and resulted in the temporarily delaying the implementation of the fiscal rules, provided that this does not endanger fiscal sustainability in the medium term (Croatian Parliament, 2013).

The establishment of the Fiscal Commission increased independence since the Commission is separated from the Ministry of Finance. For achieving the full independence, it is necessary to 
establish an independent body, which will not be linked to the executive authority. The national reform program for 2016 foresees the adoption of the new law on fiscal responsibility. The new law should be harmonized with the Directive (85/2011/ EU) and should strengthen the role and independence of the Commission for fiscal policy (Government, 2015). Consequently, the European Commission in its recommendations for national reform program put forward their views. The opinion says that the Commission is closely associated with the fiscal authorities and that they lack expert personnel. Their findings suggest that such conditions put in question the political and operational independence of the Fiscal Commission (European Commission, 2016).

\section{Fiscal council influence on budgetary consolidation}

This analysis tries to prove how the establishment of the Fiscal Council affects the fiscal consolidation. A simple analysis will cover the period from 2002 to 2015, according to data available from Eurostat and the European Commission. As an indicators of the impact of the Fiscal Council on fiscal rules, two fiscal rules will be taken: budget balance and public debt.

For selected twelve countries, there will analyzed development of the share of budget balance to GDP and the level of public debt to GDP for the period of 2012-2015. It should be noted that the observation period is short and that economic circumstances have been significantly changed. The results will provide a basic overview of relation between fiscal council and the implementation of fiscal rules. It is also important to note that the calculation does not take other circumstances that may have influenced the change in the budget balance and public debt in observed period.

Countries that will be analyzed are those that have introduced fiscal council before 2012. They are selected on that way to have their impact as credible as possible. The countries were divided into two groups, those in which the fiscal council was established before the financial crisis (up to 2007) and those in which the fiscal council was established after the beginning of the crisis (2008-2011).

Table 5. Overview of fiscal council established before and after crisis

\begin{tabular}{|l|c|l|c|}
\hline \multicolumn{1}{|c|}{ Country } & Start of activity & \multicolumn{1}{c|}{ Country } & Start of Activity \\
\hline Established before crisis & \multicolumn{2}{|c|}{ Established after crisis } \\
\hline The Netherlands & 1945 & Hungary & 2009 \\
\hline Denmark & 1962 & UK & 2010 \\
\hline Germany & 1963 & Romania & 2010 \\
\hline Belgium & 1989 & Croatia & 2011 \\
\hline Sweden & 2007 & Ireland & 2011 \\
\hline
\end{tabular}

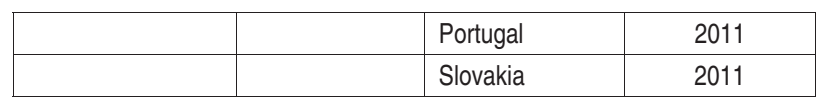

Source: national websites of fiscal councils, functions and impact of fiscal councils (IMF, 2013).

The aim of this analysis, which is divided into two groups, is to show the difference in public finance management, which is, among other things, a result of the existence of the so-called "Fiscal watchdog".

\subsection{Influence of fiscal council on the budget} balance. An analysis of the selected twelve Member States of the European Union showed following results. Budget balance in these countries moved in line with expectations due to the financial crisis of 2008, with respect that certain European countries (Portugal, Ireland, Greece and Spain) were affected by the debt crisis of 2010, which had as a consequence the introduction of stricter supranational fiscal rules.

The following table shows the average share of the fiscal balance to GDP is divided into three periods: 2002-2007 (which is considered the period before the crisis), from 2008 to 2011 (period during the crisis) and the 2012 to 2015 year (the period after the introduction of the Directive 2011/85/EU).

Table 6. The share of the average budget balance in GDP for selected countries in the pre-crisis period (2002-2007), during the crisis (2008 to 2011) and after the introduction of the Directive (2012-2015)

\begin{tabular}{|l|c|c|c|}
\hline \multicolumn{1}{|c|}{ Country } & 2002-2007 & 2008-2011 & 2012-2015 \\
\hline Belgium & -0.7 & -3.7 & -3.2 \\
\hline Denmark & 2.8 & -1.1 & -1.3 \\
\hline The Netherlands & -1.1 & -3.6 & -2.6 \\
\hline Germany & -2.8 & -2.2 & 0.2 \\
\hline Sweden & 0.8 & 0.3 & -1.0 \\
\hline Portugal & -4.6 & -8.1 & -5.5 \\
\hline Romania & -1.7 & -6.8 & -1.9 \\
\hline Slovakia & -3.6 & -5.5 & -3.2 \\
\hline UK & -3.1 & -8.3 & -6.0 \\
\hline Croatia & -3.9 & -5.7 & -4.8 \\
\hline Ireland & 1.0 & -16.4 & -5.0 \\
\hline Hungary & -7.4 & -4.6 & -2.3 \\
\hline
\end{tabular}

Source of data: Eurostat.

Calculation: authors.

When the countries are grouped into three specific periods, before the crisis, during the crisis and after the adoption of the Directive, which coincided with the debt crisis in PIGS countries, it can be concluded that the countries that have introduced pre-crisis fiscal council had much better results in terms of fiscal budget balance than other countries. From this, it can be concluded that, in the long term, fiscal council has a positive impact on creators of fiscal policy. Therefore, it is important to insist on maintaining the independence and expertise of the fiscal council. 
Table 7. Comparison of average budget balance (GDP weighted) in the countries that have established a fiscal council before the crisis and in countries that have established a fiscal council after the crisis in the period from 2002-2015

\begin{tabular}{|c|c|c|c|}
\hline Year & $\begin{array}{c}\text { Fiscal council } \\
\text { established } \\
\text { before 2008 }\end{array}$ & $\begin{array}{c}\text { Fiscal council } \\
\text { established } \\
\text { after 2008 }\end{array}$ & Difference \\
\hline 2002 & $-1.94 \%$ & $-8.27 \%$ & $6.33 \%$ \\
\hline 2003 & $-2.10 \%$ & $-6.72 \%$ & $4.62 \%$ \\
\hline 2004 & $-0.72 \%$ & $-6.11 \%$ & $5.39 \%$ \\
\hline 2005 & $0.57 \%$ & $-7.35 \%$ & $7.92 \%$ \\
\hline 2006 & $1.40 \%$ & $-8.66 \%$ & $10.06 \%$ \\
\hline 2007 & $2.38 \%$ & $-4.86 \%$ & $7.24 \%$ \\
\hline 2008 & $1.34 \%$ & $-3.72 \%$ & $5.06 \%$ \\
\hline 2009 & $-2.40 \%$ & $-5.12 \%$ & $2.72 \%$ \\
\hline 2010 & $-2.28 \%$ & $-5.03 \%$ & $2.75 \%$ \\
\hline 2011 & $-1.22 \%$ & $-5.68 \%$ & $4.46 \%$ \\
\hline 2012 & $-1.53 \%$ & $-2.73 \%$ & $1.20 \%$ \\
\hline 2013 & $-1.09 \%$ & $-2.80 \%$ & $1.71 \%$ \\
\hline 2014 & $-0.54 \%$ & $-2.51 \%$ & $1.97 \%$ \\
\hline 2015 & $-0.42 \%$ & $-2.12 \%$ & $1.70 \%$ \\
\hline Average difference: $4.51 \%$ & & \\
\hline
\end{tabular}

Source of data: Eurostat.

Calculation: authors.

Table 7 further supported by the fact that the fiscal councils in a long period of time create results in the directing fiscal policy on positive path. The average difference in the budget deficit between two groups in the period 2002-2015 was 4.51 percentage points. In other words, countries that had founded the fiscal council before 2008 have had an average of 4.51 percentage points lower deficit in comparison with the countries that established fiscal councils later. To make the analysis more credible, the average share of budget balance was weighted with GDP to avoid that problems of much larger scale in some countries (like Ireland in 2010) would not affect the results.

Figure 1 shows Member States that have established a fiscal council before the crisis have on average the surplus before the crisis (20052008), contrary to countries that have established a fiscal council after the start of the crisis, which, on average, did not recorded surplus. Following the introduction of the directive in 2011 and the establishment of fiscal councils in many EU countries, situation is changing, and the difference between these two groups of countries is much lower in the period from 2012-2015 the average is only 1.65 percentage points.

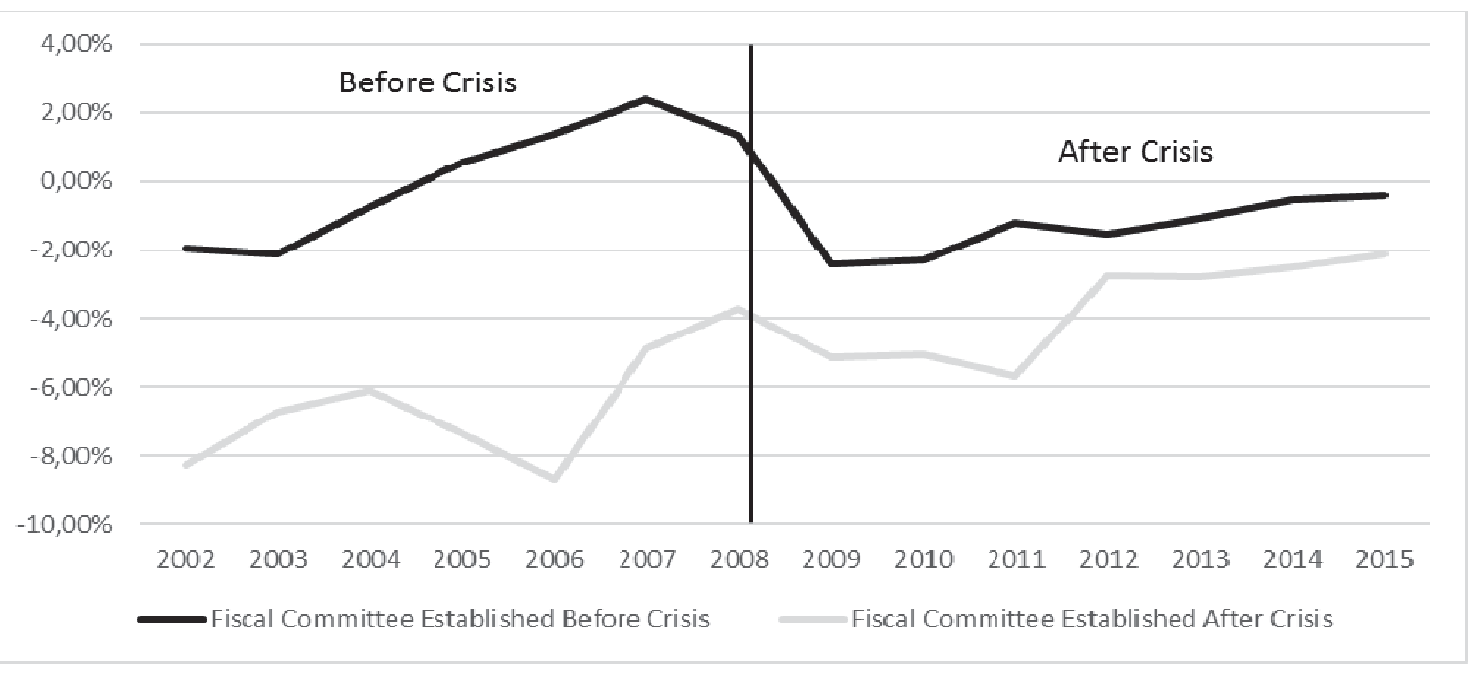

Fig. 1. Average budget balance - GDP weighted

Source: Eurostat \& authors' calculation.

3.2. Influence of fiscal council on the public debt. The second most important fiscal rule applies to the public debt and, consequently, the second analysis made in relation to the public debt to GDP. Table 8 shows the share of the average public debt ratio in the period before the crisis, during the crisis and after the introduction of the Directive. Two Member States that had largest changes in public debt to GDP averago ratio after the introduction of the Directive are Ireland and Portugal because of debt crisis.

Member States that have established a fiscal council before the beginning of the crises, on average, have less changes in public debt, as it was the case with the budget balance.

Table 8. The share of the average public debt in GDP for selected countries in the pre-crisis period (2002-2007), during the crisis (2008 to 2011) and after the introduction of the Directive (2012-2015)

\begin{tabular}{|l|c|c|c|}
\hline \multicolumn{1}{|c|}{ Country } & 2002-2007 & 2008-2011 & 2012-2015 \\
\hline Belgium & 95.8 & 98.5 & 105.5 \\
\hline Denmark & 39.3 & 40.8 & 43.7 \\
\hline The Netherlands & 47.2 & 57.9 & 66.9 \\
\hline Germany & 63.9 & 74.2 & 75.7 \\
\hline Sweden & 46.1 & 37.9 & 41.3 \\
\hline
\end{tabular}


Table 8 (cont.). The share of the average public debt in GDP for selected countries in the pre-crisis period (2002-2007), during the crisis (2008 to 2011) and after the introduction of the Directive (2012-2015)

\begin{tabular}{|l|c|c|c|}
\hline \multicolumn{1}{|c|}{ Country } & 2002-2007 & 2008-2011 & 2012-2015 \\
\hline Portugal & 63.7 & 90.7 & 128.6 \\
\hline Romania & 17.6 & 25.1 & 38.4 \\
\hline Slovakia & 36.6 & 37.1 & 53.6 \\
\hline UK & 40.1 & 69.0 & 87.2 \\
\hline Croatia & 38.8 & 53.0 & 81.5 \\
\hline Ireland & 27,1 & 75,0 & 110,4 \\
\hline Hungary & 60,3 & 77,8 & 76,7 \\
\hline
\end{tabular}

Source of data: Eurostat.

Calculation: authors.

Next table shows a comparison of the GDP weighted average rate of change in the public debt. In the Member States that have established a fiscal council before the crisis, public debt was growing 2.81 percentage points less in relation to the countries that have established a fiscal council after 2008.

Table 9. Comparison of average change of public debt (GDP weighted) in the countries that have established a fiscal council before the crisis and in countries that have established a fiscal council after the crisis in the period from 2002-2015

\begin{tabular}{|c|c|c|c|}
\hline Year & $\begin{array}{c}\text { Fiscal council } \\
\text { established before } \\
\mathbf{2 0 0 8}\end{array}$ & $\begin{array}{c}\text { Fiscal council } \\
\text { established after } \\
\mathbf{2 0 0 8}\end{array}$ & Difference \\
\hline 2003 & $0.10 \%$ & $4.44 \%$ & $4.34 \%$ \\
\hline 2004 & $-0.92 \%$ & $1.78 \%$ & $2.69 \%$ \\
\hline 2005 & $-2.11 \%$ & $3.08 \%$ & $5.19 \%$ \\
\hline 2006 & $-8.33 \%$ & $5.98 \%$ & $14.31 \%$ \\
\hline
\end{tabular}

\begin{tabular}{|c|c|c|c|}
\hline 2007 & $-8.89 \%$ & $1.40 \%$ & $10.29 \%$ \\
\hline 2008 & $6.07 \%$ & $9.87 \%$ & $3.80 \%$ \\
\hline 2009 & $12.04 \%$ & $11.54 \%$ & $-0.49 \%$ \\
\hline 2010 & $2.27 \%$ & $4.97 \%$ & $2.69 \%$ \\
\hline 2011 & $0.33 \%$ & $1.22 \%$ & $0.89 \%$ \\
\hline 2012 & $0.89 \%$ & $-2.11 \%$ & $-3.00 \%$ \\
\hline 2013 & $1.85 \%$ & $-1.46 \%$ & $-3.30 \%$ \\
\hline 2014 & $4.16 \%$ & $-0.51 \%$ & $-4.67 \%$ \\
\hline 2015 & $-4.96 \%$ & $-1.18 \%$ & $3.78 \%$ \\
\hline Average difference: $2.81 \%$ & \\
\hline
\end{tabular}

Source of data: Eurostat.

Calculation: authors.

Figure 2 shows a GDP weighted average change in public debt, which is directly linked to the three periods. In the period before the crisis, it is quite obvious that the fiscal councils influenced the conduct of fiscal policy in a way that the responsible persons for fiscal policy in five countries (Belgium, Germany, Denmark, Sweden and the Netherlands) refrain from excessive spending that has increased public debt. In times of crisis when they had to play a more active role in reducing the damage, it can be seen that they increased rates of growth of public debt almost as other countries, which introduced fiscal councils later after crisis. After almost all EU Member States under Directive introduced fiscal councils, we can seen the alignment between these two groups and even faster public debt consolidation in countries that created fiscal councils after the crisis. This is mainly attributable to the fact that it was necessary to correct mistakes of higher rate of growth of public debt before the crisis.

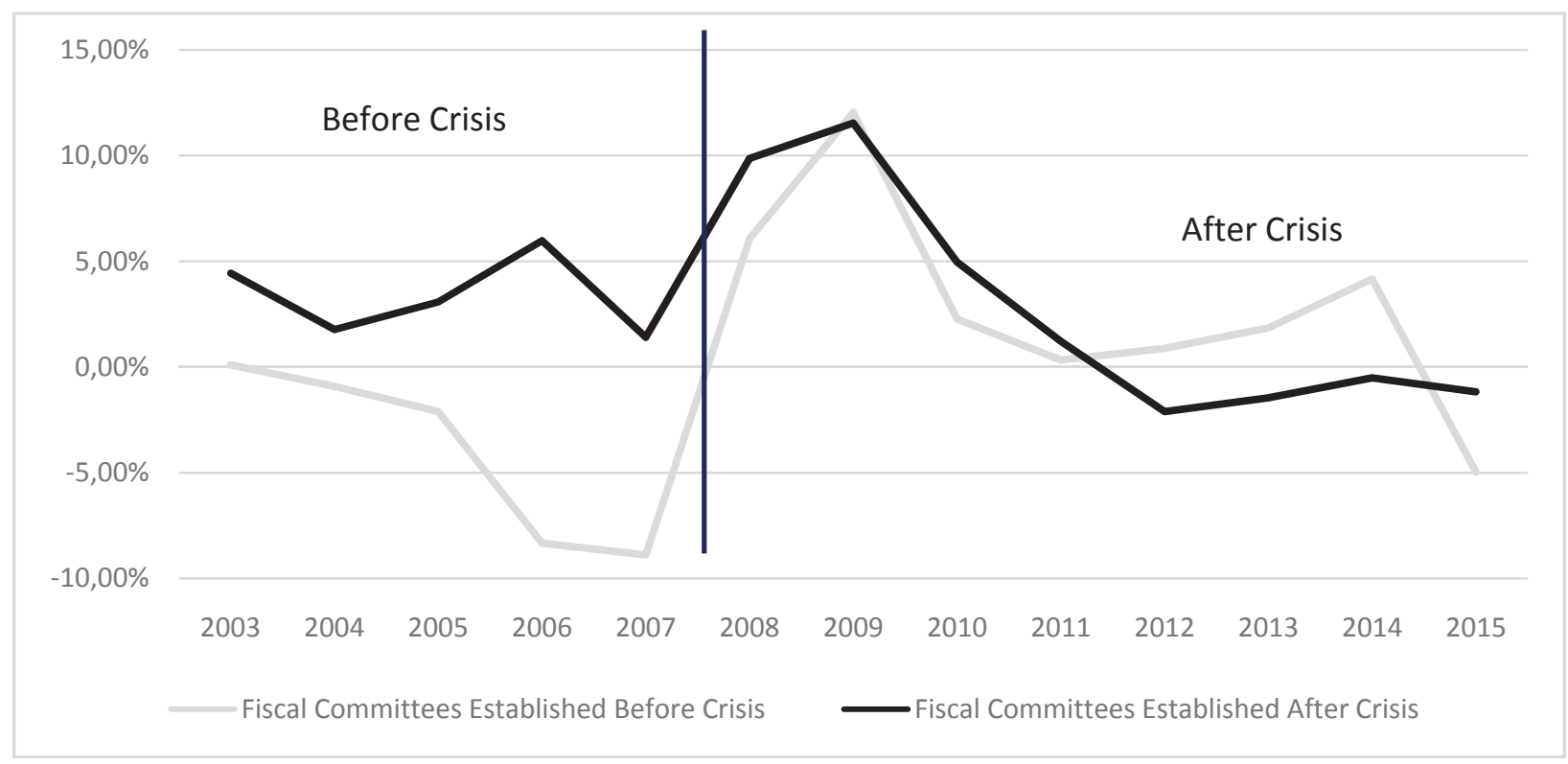

Fig. 2. Average change of public debt - GDP weighted

Source of data: Eurostat.

Calculation: authors. 
This brief analysis leads to the conclusion that fiscal councils had and still have a positive impact on fiscal policy holders to meet fiscal rules. Surely it will take additional time, and a new crisis which will show the real influence of the fiscal council on fiscal policy. Fiscal councils operate as long-term institutions and their constant surveillance of fiscal policy is of great importance.

\section{Conclusion}

This brief analysis shows the importance of fiscal Councils in modern economy. The countries which introduced fiscal councils before crisis were more resilient to the crisis than other EU countries. For those countries, long period of independent influence on public finance obviously gives positive results on long-term sustainability of public finances. In general, it is very hard to expect from politicians to run countercyclical fiscal policy in time of economic prosperity. In that context, the financial crisis was a lesson for many countries and they decided to introduce independent fiscal councils, especially after EU Directive from 2011. Following the public debt crisis in the EU, a lot of the development of a legal framework was made, that will allow a solid framework for the conduct of fiscal policy.

The implementation of the legal procedures of the "six-pack" and "two-pack" took several years, and there are first results in the stabilization of public finance in the majority of EU member states. Introduction of European fiscal council will certainly help in harmonization of functioning of fiscal councils across EU.

\section{References}

1. Beetsma, R. and Debrun, X. (2016a). Fiscal councils: Rationale and Effectiveness, CEPR Discussion Paper 11140 , and IMF Working Paper, No 16/86.

2. Beetsma, R. and Debrun, X. (2016b). Debunking 'fiscal alchemy': The role of fiscal councils. Available at: http://voxeu.org/article/debunking-fiscal-alchemy-role-fiscal-councils.

3. Calmfors, L. \& Wren-Lewis, S. (2011). What should fiscal councils do? Economic Policy, 26 (68), pp. 649-695, October 2011.

4. Croatian Parliament. (2013). Decision on The Establishment of The Fiscal Policy Commission.

5. Debrun, X., Kinda, T., Curristine, T., Eyraud, L., Harris, J. and Seiwald, J. (2013). The functions and impact of fiscal councils, IMF Policy Paper.

6. ECB. (2013). The Importance and Effectiveness of National Fiscal Frameworks in the EU, 2013.

7. European Commission. (2011). National Fiscal Frameworks, Report on Public Finances in EMU 2010, pp. 98-115.

8. European Commission. (2016). Recommendations for National Reform Program.

9. European Commission. (2012). Common principles on national fiscal correction mechanisms.

10. Government of Republic of Croatia. (2011). Decision on the Establishment of Fiscal Committee.

11. Government of Republic of Croatia. (2015). Nacionalni program reformi, 2016.

12. Von Hagen, J. (2013). Scope and limits of independent fiscal institutions, in Kopits, George (ed) (2013), Restoring public debt sustainability: The role of independent fiscal institutions, Oxford University Press.

$\begin{array}{lccc}\text { 13. IMF. } & \text { (2015). } & \text { Fiscal } & \text { Rules } \\ \text { http://www.imf.org/external/datamapper/FiscalRules/map/map.htm. }\end{array}$

Dataset. Available at:

14. Juncker, J.-C. (2015). Completing Europe's Economic and Monetary Union, European Commission

15. Wyplosz, C. (2012). Fiscal rules: Theoretical issues and historical experience, NBER Working Papers; No 17884. 